PACS: 42 Dp; 42.15Fr; 42.15.-j; 42.00 .00

\title{
ABOUT THE INFORMATIVE PARAMETERS OF MICHELSON INTERFEROMETERS WITH THE DIVISION OF AMPLITUDE AND THE WAVE FRONT
}

\author{
V.M. Svishch \\ National Aerospace University "Kharkiv Aviation Institute" \\ 17, Chkalova St., Kharkiv, 61070, Ukraine \\ E-mail: vladimir.svishh@rambler.ru, https://orcid.org/0000-0003-2903-5744 \\ Received May 12; revised June 16; accepted July 18, 2018
}

At consideration of the theory of the Michelson's experiment and conducting experiments on its scheme of dividing the amplitude of the light flux as an informative parameter, the difference $\Delta L$ in the lengths of the paths of the transverse and longitudinal rays of the light flux is used by measuring the shift of the interference pattern of the transverse and longitudinal rays. The significance of the other circuit parameters in determining the influence of the Earth's speed with the help of Michelson interferometers was not considered. The analysis of the parameters of the schemes of Michelson interferometers with the division of both the wave front amplitude and its wave front in the reference system associated with the interferometer is carried out in order to determine the influence of the interferometer speed on them. As a result of the analysis of the scheme with the division of amplitude, a linear dependence of the changes in frequency, the width of the reflected rays on the ratio $v / c$ of the device speed to the speed of light in interferometers. In the Michelson interferometer scheme with wave front division, the difference $\Delta L$ of paths length and the ray deflection angles are linearly dependent on the ratio of the device speed to the speed of light $v / c$.These additional dependences are determined by the collinearity of the reflected rays and the speed of the observer's movement, in contrast to their perpendicularity in the interferometer with the division of the wave front amplitude. As a result of the comparison of the parameters in the reference system associated with the interferometer, it is concluded from their significance that the use of frequency changes, the width of the reflected rays in the interferometer with amplitude division, and the wave front interferometer, the difference in the path lengths $\Delta L$ of the rays, frequency, angle of deflection and the width of the reflected rays is preferable.

KEYWORDS: Michelson interferometer, light aberration, reference system, amplitude and wave front division of the light flux, light-flux frequencies, angle of the ray rejection, width of light stream, device speed.

\section{ПРО ІНФОРМАТИВНІ ПАРАМЕТРИ ІНТЕРФЕРОМЕТРІВ МАЙКЕЛЬСОНА 3 РОЗПОДІЛОМ АМПЛІТУДИ І ХВИЛЬОВОГО ФРОНТУ \\ В.М. Свищ}

Харківський начіональний аэрокосмічий університет ім. М.Е. Жуковського «Харківський авіаційний інститут» вул. Чкалова 17, Харків, Украӥна, 61070

При розгляді теорії експерименту Майкельсона і проведенні експериментів по його схемі розподілу амплітуди світлового променя в якості інформативного параметра використовується різниця довжин шляхів поперечного та поздовжнього променів. Інформативність інших параметрів схем при визначенні впливу швидкості руху Землі за допомогою інтерферометрів Майкельсона не розглядалася. Проведено аналіз параметрів схем інтерферометрів Майкельсона 3 розподілом як амплітуди світлового променя так і його хвильового фронту в системі відліку, пов'язаній з інтерферометром, 3 метою визначення впливу на них швидкості руху інтерферометрів. В результаті аналізу схеми 3 розподілом амплітуди показана лінійна залежність змін частоти, ширини відбитих променів від відношення $v / c$ швидкості приладу до швидкості світла. У схемі інтерферометра Майкельсона з розподілом хвильового фронту додатково лінійно залежать від ставлення швидкості приладу до швидкості світла $v / c$ різниця $\Delta L$ довжин шляхів і кути відхилення променів. Ці додаткові залежності визначаються колінеарністю відбитих променів і швидкості руху спостерігача на відмінність їх перпендикулярності в інтерферометрі з поділом амплітуди. В результаті порівняння параметрів в системі відліку, пов'язаній з інтерферометром, за ïx інформативностю робиться висновок про перевагу застосування змін частоти, ширини відбитих променів в інтерферометрі з розподілом амплітуди, а в інтерферометрі з розподілом хвильового фронту - різницею довжин шляхів $\Delta L$ променів, частоти, кута відхилення і ширини відбитих променів .

КЛЮЧОВІ СЛОВА: швидкість приладу, схеми інтерферометрів Майкельсона, розподіл амплітуди, розподіл хвильового фронту, аберація світла, система відліку, , частоти світлових потоків, кут відхилення променя, ширина променя.

\section{ОБ ИНФОРМАТИВНЫХ ПАРАМЕТРАХ ИНТЕРФЕРОМЕТРОВ МАЙКЕЛЬСОНА С ДЕЛЕНИЕМ АМПЛИТУДЫ И ВОЛНОВОГО ФРОНТА \\ В.М.Свищ}

Харьковский национальный аэрокосмический университет им. М.Е. Жуковского «Харьковский авиационный институт» ул. Чкалова 17, Харьков, Украина, 61070

При рассмотрении теории эксперимента Майкельсона и проведении экспериментов по его схеме деления амплитуды светового потока в качестве информативного параметра используется разность длин путей поперечного и продольного лучей. Информативность других параметров при определении влияния скорости движения Земли с помощью интерферометра Майкельсона не рассматривалась. Проведен анализ параметров схем интерферометров Майкельсона с делением как амплитуды светового потока так и его волнового фронта в системе отсчета связанной с интерферометром с целью определения влияния на них скорости движения интерферометра. В результате анализа схемы с делением амплитуды показана линейная зависимость изменений частоты, ширины отраженных лучей от отношения $v / c$ скорости прибора к скорости света. В схеме интерферометра Майкельсона с делением волнового фронта дополнительно зависят линейно от 
отношения $v / c$ разность длин путей и углы отклонения лучей. Эти дополнительные зависимости определяются коллинеарностью отраженных лучей и скорости движения наблюдателя в отличие от их перпендикулярности в интерферометре с делением амплитуды волнового фронта. В результате сравнения параметров в системе отсчета связанной с интерферометром по их информативности делается вывод о предпочтительности использования изменений частоты, ширины отраженных лучей в интерферометре с делением амплитуды, а в интерферометре с делением волнового фронта разности длин путей лучей, частоты, угла отклонения и ширины отраженных лучей.

КЛЮЧЕВЫЕ СЛОВА: скорость прибора, схемы интерферометров Майкельсона, деление волнового фронта, деление амплитуды, аберрация света, система отсчета, угол отклонения луча, ширина луча.

The Michelson interferometer using the amplitude of the light flux has received a wide application in scientific research and industry. This scheme, comparing the lengths of light flux, Michelson applied in the experiment to determine the motion of the Earth relatively to the ether [1].

In another interferometer for astronomical studies, Michelson realized the scheme with wave front division, but not its amplitude [1,2]. The scheme proposed by Fizeau was significantly improved and implemented by Michelson while measuring the stars diameters, where the lengths of the light-path paths are also compared. At present, this significantly modified scheme is widely used by astronomers in interferometry with a large base [3].

The informative possibilities of other parameters, except comparing the lengths of the light flux paths, in these schemes were not previously considered.

Purpose of the work is estimation of an information parameters for selection them by using Michelson interferometer.

\section{ANALYSIS OF INFORMATIVE PARAMETERS OF THE MICHELSON INTERFEROMETER SCHEME BY DIVIDING THE AMPLITUDE OF THE LIGHT FLUX}

Michelson tried to determine the speed of Earth motion relatively to the ether as a medium of light propagation. The science has already said goodbye to such a representation of the ether. However, considering the independence of the speed of light from the speed of the source, Michelson could determine the speed of the Earth relatively to the light flux. Taking it into account, let us consider the possible informative parameters of the Michelson experiment.

More than 130 years passed after the first conduct of the Michelson experiment with its interferometer based on the division of the amplitude of the light flux (Fig. 1), but the interest to its theory and results does not fade. This is evidenced by a periodic repetition of experiments beginning with the Michelson experiment (1881) with an increase in the accuracy of their results and a review of its theory by various authors [3, 4, 5,7 - 12, $15-19]$.

Further repeated repetitions of the experiment with an increase in accuracy to $10^{-6}$ and more finally confirmed the negative result of the experiment. This undoubtedly raises the question of the theory of the experiment, which predicts significant shifts in the interference pattern up to units of the interference fringe.

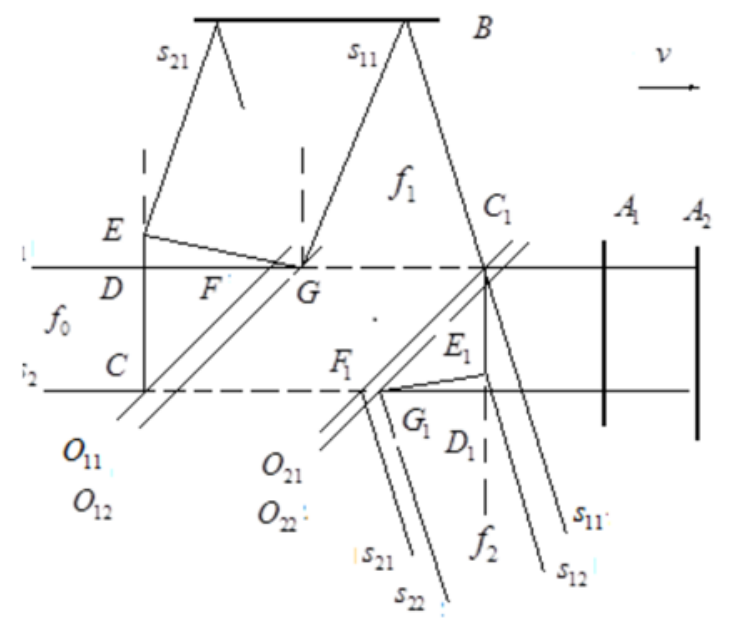

Fig. 1. The path of the rays, taking into account their widths in the reference system associated with the light fluxes in the interferometer with the division of the amplitude of the wave front

The theory of the experiment since Michelson was repeatedly considered by many authors [3, 5, $7-11,14-19]$. In all these studies, the expected shift in the pattern of the picture is confirmed by a value of the second order $2 L \frac{v^{2}}{c^{2}}(\mathrm{~L}-$ the length of the arm of the interferometer, $v$ - the speed of the interferometer in the direction of the longitudinal arm of the interferometer, $c$ - the speed of light). However, they did not analyze the effect of the deviation of the transverse ray on the expected result of the experiment of its cause.

The problem of the reflection of light from a moving mirror was first considered by A. Einstein [4]. At first in this work A. Einstein recounts frequency, angle of incidence and amplitude of the light stream from the coordinate system with the mirror moving in it to the coordinate system where the mirror is immobile. In this system he determines the 
quantities related to the reflected wave. Then he performs a reverse transition to the coordinate system with the moving mirror. The problem is solved in general form without taking into account the ray width.

Later [5] while analyzing the Michelson's experiment with an interferometer, based on the division of the amplitude of the light flux, Sommerfeld unambiguously indicates the aberration of the light flux on a semitransparent mirror. This aberration provides meeting of the transverse and longitudinal rays in the system with the immobile mirror based on a mirror shifted relatively to the light flux and entering it in the observer's tube.

"On the contrary, the angle $\alpha^{\prime}$ differs in the primed system on a small value of the first order (we can call it the aberration angle);" P.104 "The fact that light exactly falls into the shifted observer's B telescope is provided by changing the law of reflection when reflected from a moving mirror $H$ in its position $H^{\prime} "[5]$.

However, he does not analyze the effect of the aberration angle on a moving mirror with an active change in the direction of the reflected light flux on the measurement results.

Such analysis was given in by Sokolov [10] with the construction of the wave front of a transverse light flux. The result of his analysis indicates the complete equality of the paths of the transverse and longitudinal rays. Thus, the expected shift of interference fringes due to equality of paths should be absent.

The determination of the difference in the lengths $\Delta L$ of the paths of the transverse and longitudinal rays of the light flux by measuring the shift of the interference pattern of the transverse and longitudinal rays is an informative parameter with all the considerations of the theory of the Michelson's experiment and the conduction of experiments. The results of numerous experiments using this informative parameter in the Michelson scheme unambiguously indicate the absence of difference $\Delta L$ as a result of Lorentz's contraction of the longitudinal dimensions of the interferometer or due to the equality of the compared optical paths.

$$
\Delta L=0
$$

Let's consider other possible informative parameters of the scheme with allowance for the aberration of light on the mirrors - the widths and angles of the deviation of the transverse and longitudinal rays, the difference in their frequencies. To do this, let's analyze the experimental scheme in the reference system associated with the light fluxes (Fig. 1) and in the reference frame associated with the mirrors (Fig. 2).

Fig. 1 shows the Michelson's scheme, taking into account the finite width of the light fluxes in the plane of their propagation.

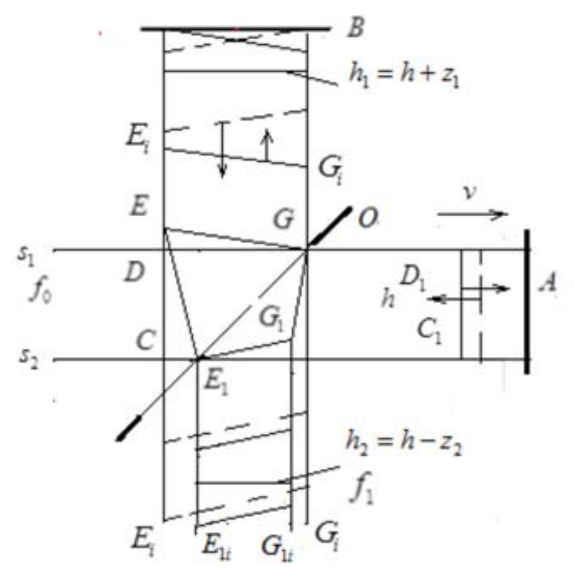

Fig. 2. The path of the rays, taking into account their widths in the reference system associated with the interferometer with division of the amplitude of the wave front

Here, $s_{1}, s_{2}$ are the outermost rays of the initial light flux with a frequency $f_{0}$ with width $C D=h$, $\mathrm{O}_{11}, \mathrm{O}_{12}, \mathrm{O}_{21}, \mathrm{O}_{22}$ - the positions at different times with respect to the transverse light flux of the translucent mirror $\mathrm{O}$, mounted at an angle $45^{\circ}$ to the light flux CD, A, B - the blind mirrors, $\mathrm{v}$ - the speed of the system in the direction of light flux CD propagation.

The wave front of the light stream $\mathrm{CD}$ hits the mirror $\mathrm{O}$ in position $O_{11}$ when the ray $S_{2}$ is reflected from the mirror at a point $\mathrm{C}$, and the ray $s_{1}$ from the point $\mathrm{D}$ will still catch up with the mirror $\mathrm{O}$ till the point $\mathrm{G}$ in position $O_{12}$. During the time of passage of the ray $s_{1}$ of the wave front CD of the path DG (Fig. 1) the mirror O moves from position $O_{11}$ to position $O_{12}$ and the ray $s_{1}$ reflects from the mirror $\mathrm{O}$ at the position $O_{12}$ at the point G. Let's the displacement of the mirror $\mathrm{O}$ from the position $O_{11}$ to the position $O_{12}$ equal to FG will be equal to $z_{1}$, and the transit time of the ray $s_{1}$ of the path $D G=D F+F G$ will be equal to $t_{1}$. Then the ray $s_{2}$ for the time $t_{1}$ after the reflection from the mirror $\mathrm{O}$ in the position $O_{11}$ will pass the path $C E=C D+D E=D F+F G=h_{1}=h+z_{1}$. The wave front CD after reflection from the mirror $\mathrm{O}$ in accordance with the construction on the basis of the Huygens-Fresnel principle will be EG. This 
wave front $\mathrm{EG}$ is rotated relatively to the direction $\mathrm{CE}$ by $\angle \beta \operatorname{tg} \beta=\frac{D E}{D G}, D E=F G, \frac{D G}{c}=\frac{F G}{v}$. Without taking into account second-order quantities

$$
\operatorname{tg} \beta=\frac{v}{c}
$$

Further, reflecting from the mirror $\mathrm{B}$ at an angle $-\angle \beta$, the wave front overtakes the mirror $\mathrm{O}$ in position $O_{21}$ at this angle. The width of the reflected wave front will be $E G>D G=h_{1}$

$$
h_{1}=h+z_{1} \text {. }
$$

On the other hand, on the mirror $\mathrm{O}$ in the position $O_{21}$ the wave front $C_{1} D_{1}$ comes of the part of the initial light flux reflected by the blind mirror $\mathrm{A}$ in position $A_{2}$. Its ray $s_{1}$ is reflected from the mirror $\mathrm{O}$ in the position $O_{21}$ at the point $C_{1}$ spreading in the direction $C_{1} D_{1}$. The ray $S_{2}$ hits the mirror $\mathrm{O}$, which has shifted to $F_{1} G_{1}=z_{2}$ during the time $t_{2}$ the ray $S_{2}$ travels the path $D_{1} G_{1}$ to the position $O_{22}$, at the point $G_{1}$. During the same time $t_{2}$, the ray $s_{1}$, reflected from the mirror $\mathrm{O}$ in the position $O_{21}$ at the point $C_{1}$, will pass the path $C_{1} E_{1}=C_{1} D_{1}-F_{1} G_{1}$. Since $F_{1} G_{1}=z_{2}$, then the path of the ray $s_{1} C_{1} D_{1}=C_{1} E_{1}=h_{2}=h-z_{2}$. Width of the reflected wave front $C_{1} E_{1}>D_{1} G_{1}=h_{2}$

$$
h_{2}=h-z_{2}
$$

The wave front $C_{1} D_{1}$ after reflection from the mirror $\mathrm{O}$ will became $E_{1} G_{1}$, in accordance with the construction on the basis of the Huygens-Fresnel's principle. It will be deployed on $\angle-\beta \operatorname{tg} \beta=\frac{D_{1} E_{1}}{D_{1} G_{1}} \operatorname{tg} \beta=v / c$, and spread at the same angle with the wave front $\mathrm{CD}$

$$
\operatorname{tg} \beta=\frac{v}{c}
$$

Let us consider in more detail the width of the transverse and longitudinal wave fronts in the plane of propagation of the light fluxes (Fig. 1).

Let's denote the width of the wave fronts in the plane of propagation of the incident (original) $L=h=D C=$ $D_{1} C_{1}$ transverse $H_{1}=E G, H_{2}=E_{1} G_{1}, \frac{D G}{c}=t_{1}, \frac{D_{1} G_{1}}{c}=t_{2} z_{1}=F G=E D z_{2}=F_{1} G_{1}=E_{1} D_{1}$ light fluxes.

The width of the rays formed by the reflected wave fronts, hence $h_{1}=h+z_{1}, h_{2}=h-z_{2}$.

So the width of the wave fronts is bigger than the width of the reflected rays $H_{1}>h+z_{1} ; z_{1}=v t_{1} ; t_{1}=$ $\frac{h+z_{1}}{c} ; \frac{E D}{E G}=\frac{E_{1} D_{1}}{E_{1} G_{1}}=\sin \beta ; \beta=\angle E G D=\angle E_{1} G_{1} D_{1} ; \sin \beta \approx \operatorname{tg} \beta=\frac{E D}{D G}=\frac{E_{1} D_{1}}{D_{1} G_{1}} ; \sin \beta=\frac{v}{c} ; z_{1} c=v h+v z_{1} ; z_{1}=$ $\frac{h v}{c-v} ; H_{1}=\frac{z_{1}}{\sin \beta}, H_{1}=z_{1} \frac{c}{v} ; H_{1}=\frac{h c}{c-v}$.

On the other hand, $H_{2}>h-z_{2} ; z_{2}=v t_{2} ; t_{2}=\frac{h-z_{2}}{c+v} ; z_{2}=h \frac{v}{c+v} ; H_{2}=\frac{z_{2} c}{v} ; H_{2}=\frac{h c}{c+v}$.

The difference in the width of the reflected wave fronts will also be $\Delta H=H_{1}-H_{2} ; \Delta H=\frac{h c}{c-v}-\frac{h c}{c+v}=$ $h c \frac{c+v-c+v}{c^{2}-v^{2}}=2 h \frac{v c}{c^{2}-v^{2}}$.

Thus, the width of the reflected wave fronts differs in the value of the first order

$$
\Delta H>2 h \frac{v}{c}
$$

The change in the angle $\angle \beta$ of deflection of the reflected light flux can be another informative parameter.

As Sommerfeld showed the angle of reflection won't change at reflection from deaf mirrors in the longitudinal and transverse arms of the interferometer. The angles of reflection will change only at a reflection from a semitransparent mirror [5].

A detailed analysis of the deviation of the reflected light flux from the reflector in a system with a moving reflector is given in $[4,5,10,12]$.

Unlike passive aberration in a telescope, where the light flux does not change its direction, and the telescope adjusts to the observation conditions, the light aberration on the moving mirror is active, as the reflected light flux changes direction in comparison with the direction at reflection from the stationary mirror.

In A. Michelson's experiment, the mirror moves with the observer (the system $k$ by A. Einstein). Its results can be interpreted as confirming the difference in the angles of incidence and reflection on a mirror moving with the observer the angle of reflection in the transverse arm is not equal to $45^{\circ}$.

Vavilov directly indicates the magnitude of the deviation $v / c$ of this angle.

"The ray $s a$ will be reflected along $a b$ (Fig. 9.2), thus the angle $b_{1} a b$ will be equal to $v / c$; the returning ray will go along $b a_{1}$ (angle $a b a_{1}=2 v / c$ ) into the focus of the telescope. The ray $a c$ will return in the previous direction, but, 
reflecting from the mirror moving in the ether in $a_{1}$, it will go along the $a_{1} e$ (angle $c a_{1} e=\frac{\pi}{2}-v / c$ ), coinciding with the first ray. "[11]. The same value is confirmed by the analysis $(2,5)$

$$
\operatorname{tg} \beta=\frac{v}{c}
$$

It would seem that by observing changes in the angle of the coincident ray with the telescope, it is possible to calculate the speed $v$ relatively to the transverse light flux. Let us therefore consider the path of the rays in the reference system associated with the instrument of observation. In this case, the device moves at a speed $v$ relatively to the light fluxes due to the independence of their speed of movement from the motion of the light source and the observer (Fig. 2).

The wave front of the light flux $C D$ hits the mirror $O$ when the ray $s_{2}$ is reflected from the mirror at a point $C$, and the ray $s_{1}$ will still move from the point $D$ up to the point $G$ on the mirror $O$. During the time of passage of the ray $s_{1}$ of the wave front $C D$ of the path $D G$ (Fig. 2), the reflected ray $s_{2}$ will lag behind the mirror $O$ in the reference system connected with the device, pass the path $C E$ and will be at the point $E$. The reflected wave front $E G$ of the light flux $C D$ will have a width $L_{1}>h+z_{1}$ and will be expanded relatively to the direction $C E$ on $\angle \beta$ (2). By keeping the turn at an angle $\angle \beta$, the wave front $E G$ will move on a direction $C E$ perpendicular to the longitudinal ray.

From the moment $t_{0}$ after reflection from the mirror $O$, the wave front $E G$ will traverse the path $c t_{i}$ at a time $t_{i}$ at an angle $\beta=\arcsin \frac{v}{c}$ to the direction $C E$ perpendicular to the mirror $B$ and take up position $E_{i} G_{i}$. During this same time, the reference system with the mirror $O$ will shift relatively to the initial position by a distance $v t_{i}$ in the direction of the mirror $A$. The wave front $E_{i} G_{i}$ at the moment $t_{i}$ will be above the mirror $O$ in the direction of the perpendicular to the mirror $B$, since the ratio of displacement $v t_{i}$ to path $c t_{i}$ is equal $\sin \beta=\frac{v t_{i}}{c t_{i}}=\frac{v}{c}$.

Consequently, any wave front at each instant of time is on the direction perpendicular to the longitudinal ray.

Thus, the transverse light flux formed from the wave fronts $E_{i} G_{i}$ in the direction of the mirror $B$ in the observer system will be perpendicular to the longitudinal light flux.

Similarly, the part $C_{1} D_{1}$ of the transmitted through the semitransparent mirror light stream after reflection from the mirrors $A$ and $O$ is converted into a light flux with a wave front $E_{1} G_{1}$ unfolded relatively to the direction $E C$ of $\angle \beta$. The ray with width $h_{2}=h-z_{2}$ formed from the wave fronts $E_{l i} G_{l i}$ is propagated in conjunction with the light flux $E_{i} G_{i}$ reflected from the mirror $B$ by a width $h_{1}=h-z_{1}$ perpendicular to the longitudinal light flux with the width $h$. The difference $\Delta h$ of the width of the rays in the observer system is equal to

$$
\Delta h>2 h \frac{v}{c} .
$$

The angle of observation of the interference picture is also equal to direct in relation to the direction of propagation of the longitudinal ray and does not depend on the speed $v$ of the observer.

The transverse light flux undergoes two reflections - from set under the angle of $45^{\circ}$ semitransparent mirror moving in the direction of propagation of the light flux, and from a deaf mirror moving tangentially to the light flux. As a result of the Doppler effect, when reflected from a semitransparent mirror $O$, its frequency changes by $-\Delta f_{1}$ and does not change when reflected from a moving tangentially deaf mirror $B[1,8,10]$.

$$
f_{1}=f_{0}-\Delta f_{1}
$$

where $f_{1}-$ is the frequency of the transverse light flux at the output, $f_{0}$ - the frequency of the input light flux, $\Delta f_{1}-$ frequency change after reflection from the mirror at the angle of incidence $45^{\circ}$, sign \pm is depending on the direction of the speed $v$.

The longitudinal light flux is reflected from the deaf mirror $A$ moving in the direction of propagation of the light flux and from the semitransparent mirror $O$ moving towards the propagation of the light flux. The change in the frequency of the light flux reflected by the mirror moving in the direction of propagation of the light flux depends on the angle of incidence nonlinearly. However, if we assume that at an angle of incidence $0^{\circ}$ the change in the frequency of the reflected light flux $\Delta f_{2}$ is twice as large as its change $\Delta f_{1}$ at an angle of incidence $45^{\circ} \Delta f_{2}=2 \Delta f_{1}$, the frequency of the longitudinal light flux $f_{2}$ at the output will be

$$
f_{2}=f_{0}-\Delta f_{2}+\Delta f_{1},
$$

where $f_{2}$ - is the frequency of the longitudinal luminous flux at the output, $\Delta f_{2}$ - the frequency change after reflection from the mirror at an angle of incidence $0^{\circ}$. I.e.:

$$
f_{2}=f_{0}-\Delta f_{1} .
$$


Thus, the frequencies of the transverse and longitudinal light fluxes at the output will be equal, but differ from the frequency of the input light flux

$$
f_{1}=f_{2}=f_{0}-\Delta f_{1}
$$

If the equality $\Delta f_{2}=2 \Delta f_{1}$ is not met, then the frequencies of the components of the output light flux will differ slightly from each other. However, their frequencies are still different from the frequency $f_{0}$ of the input light flux.

Let us consider the informative parameters of the Michelson's interferometer by dividing the wave front.

ANALYSIS OF INFORMATIVE PARAMETERS OF THE FIZEAU - MICHELSON SCHEME

Fizeau's scheme actually represents the interferometer according to the Jung's scheme with spaced apart slits for a distance $D$. The Michelson replaced the slits with the mirror system [1,5], which ensured the constancy of period of the interference pattern $\left(M_{3}, M_{4}\right)$ and the possibility of adjusting by mirrors $\left(M_{1}, M_{2}\right)$ the correlation of their light fluxes .

Let the mirrors $M_{3}, M_{4}$ be semitransparent and set the screen $E_{2}$ at a distance $d / 2$ between them (Fig. 3). The distances between the mirrors $M_{1} M_{3}$ and $M_{2} M_{4}$, accordingly are equal to $a_{1}, a_{2}$. Let us perform an analysis of such a scheme of the Michelson's interferometer in a reference system coupled with the interferometer on Fig. 4 when it moves with speed $v$ in the direction $M_{2} M_{1}$ in the reference system associated with the light fluxes $s_{1} s_{2}$.

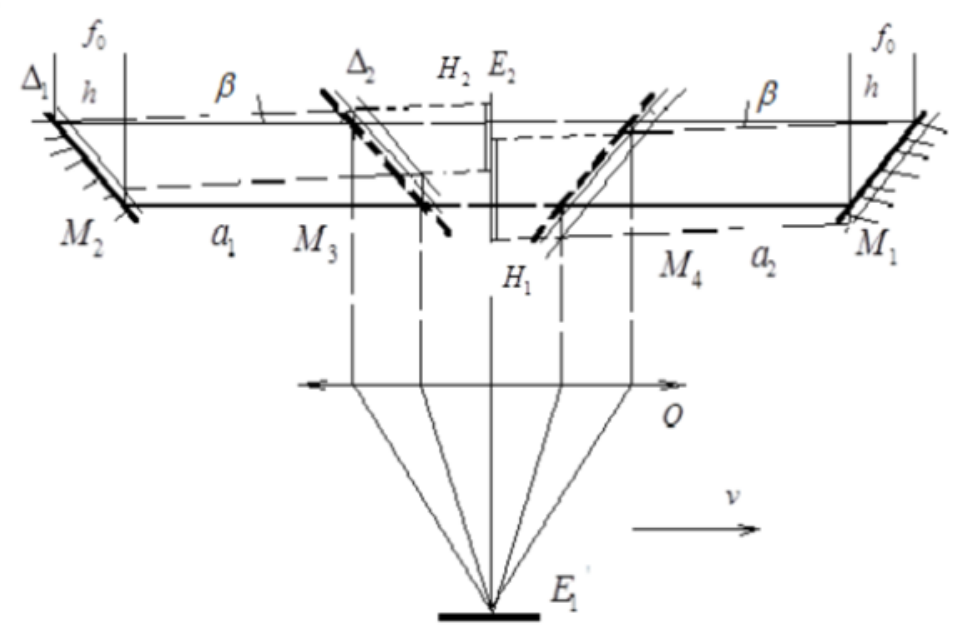

Fig.3. Scheme of the Michelson interferometer with the division of the wave front with semitransparent mirrors $M_{3}, M_{4}$ and a screen $E_{2}$

The path of the rays in this reference frame is shown in Fig.4 with designations of the rays identical to Fig. 1,2.

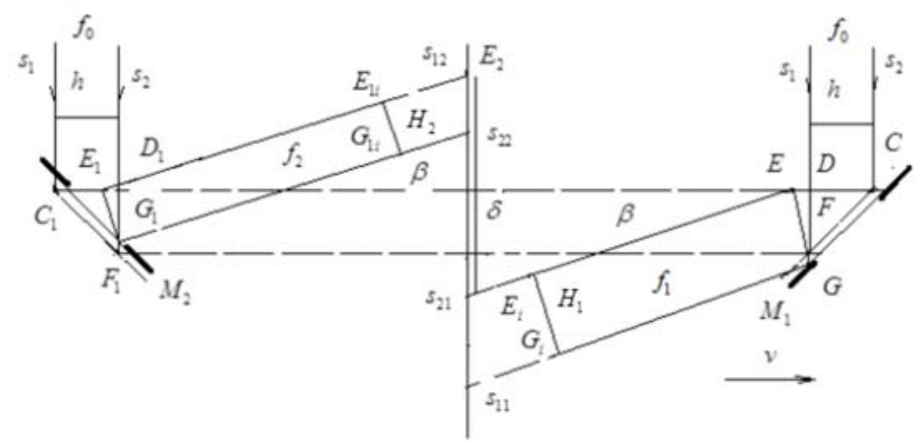

Fig. 4. The path of the rays, taking into account their width with division of the wave front in the reference system associated with the interferometer

The arms $a_{1}, a_{2}$ of the interferometer are directed along the speed $v$ of its motion. Then, the lengths $a_{11}, a_{12}$ of paths of the light flux in the reference system associated with the interferometer will accordingly be equal to $a_{11}=$ $a_{1}+\Delta a_{1} ; a_{12}=a_{2}+\Delta a_{1}$, where $\Delta a_{1}, \Delta a_{2}$ - the increases of lengths of light streams paths caused by motion of interferometer.

Similar to the longitudinal arm of the Michelson interferometer (Fig. 1), we have

$$
\frac{a_{1}+\Delta a_{1}}{c}=t_{1}, \Delta a_{1}=v t_{1}, \Delta a_{1}=a_{1} \frac{v}{c-v} ; \frac{a_{2}-\Delta a_{2}}{c}=t_{2}, \Delta a_{2}=v t_{2}, \Delta a_{2}=a_{2} \frac{v}{c+v} .
$$




$$
a_{11}=a_{1}\left(1+\frac{v}{c-v}\right), a_{11}=a_{1} \frac{c}{c-v}, a_{12}=a_{2}\left(1-\frac{c}{c+v}\right), a_{12}=a_{2} \frac{c}{c+v} .
$$

The difference in the paths of the light flux in the arms will be

$$
a_{1}=a_{2}=a \Delta a=a_{11}-a_{12} ; \Delta a=a\left(\frac{c}{c-v}-\frac{c}{c+v}\right)=2 a \frac{c v}{c^{2}-v^{2}} ; \Delta a>2 a \frac{v}{c} .
$$

Or otherwise

$$
\Delta a=\Delta a_{1}+\Delta a_{2}=a\left(\frac{v}{c-v}+\frac{v}{c+v}\right), \Delta a=a \frac{2 c v}{c^{2}-v^{2}}, \Delta a>2 a \frac{v}{c}
$$

Similarly, when reflected at an angle $45^{\circ}$ from the mirrors, the frequency of the light fluxes will change $f_{1}=f_{0}-$ $\Delta f_{1}, f_{2}=f_{0}+\Delta f_{1}$. The difference in the frequencies of the light fluxes that fall on the screen $E_{2}$ after reflection from the mirrors $M_{1} M_{2}$ will be

$$
\Delta f=2 \Delta f_{1} .
$$

The frequency of the light fluxes on the screen $E_{1}$ (Fig. 4) won't change due to additional reflections from the mirrors $M_{3}, M_{4}$.

With the width $h=D C=D_{1} C_{1}$ of the separated wave fronts from the common wave front, the reflected rays will have a corresponding width $H_{1}=\frac{h c}{c-v}, H_{2}=\frac{h c}{c+v}$.

The width of the reflected rays in the plane of their propagation, as well as in the Michelson's interferometer (Fig. 1) differs by the value $\Delta H$ (6)

$$
\Delta H>2 h \frac{v}{c} .
$$

Also the angles of the reflected light fluxes will change in contrast to the scheme with amplitude division (Fig. 2) and in the reference system associated with the interferometer will be

$$
\pm \beta=\frac{v}{c}
$$
value

Accordingly, when they meet on the screen, their cross sections will be displaced in the propagation plane by an

$$
\delta=\left(a+\frac{d}{2}\right) \sin \beta .
$$

Let's compare the results of the analysis of the informative parameters of Michelson's interferometers.

The difference $\Delta L$ of the lengths of the light flux rays paths is observed due to the shift of the interference picture of the interferometer (Fig. 1). It is equal to the zero, taking into account the Lorentz reduction of the longitudinal dimensions of the interferometer or due to the equality of the compared optical paths and confirmed by the results of numerous experiments (1). In the interferometer (Fig. 3,4) this difference is directly proportional to the arms lengths of the interferometer and the ratio $v / c$ in the first degree (13).

The change in the frequency of the transverse and longitudinal light fluxes when reflected from the moving mirrors in accordance with the Doppler effect of the first interferometer output will be equal, but differ from the frequency of the input light flux (10). In the second interferometer on the screen $E_{1}$ they are equal to the frequency of the input light flux, but in the interferometer arms on the screen $E_{2}$ they are different (12).

The width of the reflected rays in the plane of propagation in both interferometers differs by one value $(6,13)$. However, in the interferometer (Fig. 1) they are distributed along the midline, which makes it difficult to measure their difference.

The angle of deflection $\beta$ of the reflected wave fronts of the light fluxes depends on the ratio $v / c$ in the first degree also in both interferometers.

However, in the first interferometer when the reflected rays are formed in the reference system associated with the interferometer, the deflection angle is compensated by the lag of the wave fronts. The formed reflected rays are orthogonal to the longitudinal ray (Fig. 2).

In the interferometer (Fig. 3,4) the formed reflected rays are deflected at an angle $\beta$ since their wave fronts propagate parallel to the speed of the interferometer. Its registration is facilitated by measuring the displacement of the cross sections of the rays on the screen $E_{2}(15)$.

Thus, a propagation angle for the speed direction of the device has the significant influence on the informative value of difference of the ways in the reference system, connected with the interferometer, reflected rays and their angles of deflection. 
The influence of motion $\left(\Delta t, \Delta r\right.$ of the second order $\left.v^{2} / c^{2}\right)$ determined by the Lorentz transformations cannot be taken into account when measuring the order values $v / c$ in view of its comparatively small magnitude.

\section{CONCLUSIONS}

1. In addition to the parameter of the difference $\Delta L$ in the lengths of the pathways of the light flux rays, the changes in the frequency of the rays of the light flux, their width in the propagation plane and the angle of deviation of the reflected light fluxes have essential informative value.

2. These parameters depend on the ratio $v / c$ in the first degree in both interferometers except for the parameter of the path length difference $\Delta L$ and the ray deflection angle in the interferometer (Fig. 1).

3. An essential difference between these schemes, which determines the differences in their informative parameters in the reference system associated with the interferometer, is the orientation of the reflecting mirror with respect to the incident light fluxes and the speed of the device, which determines the direction of propagation of the reflected rays relatively to the speed of the device.

4. Based on the convenience of observation, changes in the frequency, the width of the reflected rays in the interferometer (Fig. 1), and the difference $\Delta L$ in the path lengths of the rays, the frequency, the deflection angle, the width of the reflected rays in the interferometer (Fig. 3, 4) are the preferred parameters.

\section{REFERENCES}

1. Michelson A. Research on optics. - M.: URSS, 2004. - P.200 (P. 34 -40, 125 - 134).

2. Michelson A., Pease F., Pearson F. Repetition of the Michelson-Morley experiment // JOSA. - 1929. - Vol.18. - No. 3. P.181-182.

3. Miller D.C., Significance of the ether-drift experiments of 1925 at Mount Wilson // Science. - 1926. - Vol. 63. - P. 433-443.

4. Einstein A. To the electrodynamics of moving bodies. Collected works. - 1987. - Vol. 1. - P. 8-10. 24-31.

5. Sommerfield A. Vorlesungenuber Teoretische Physik. Rand 4. Optic von Arnold Sommerfeld. - Wisbaden, 1950. - P. 102-114.

6. Lorentz G.A. The theory of Electrons. - Leipzig, 1916. - P. 247 -289.

7. Gimmelfarb B.N. To an Explanation of Stellar Aberration in the Theory of Relativity // Uspechi Physicheskich Nauk. - 1953. Vol. 51.

8. Frankfurt W.I., Frank A.M. Optics of Moving Bodies. - M.: Nauka, 1972. - P. 76 - 112. (in Russian)

9. Landsberg T.S. General Physics. Optic. - M.: Nauka, 1976. - P. 928. (in Russian)

10. Sokolov V.M. About the inconsistency of the Einstein A. theory of relativity // Modern high technologies. - 2008. - No. 6. P. $35-40$.

11. Vavilov S.I. Experimental foundations of the theory of relativity. Collected works. - M.: PhysMathGiz, 1965. - Vol. 4. P. 18-35. (in Russian)

12. Bolotovsky B.M., Stolyarov S.N. Reflection of light from a moving mirror and related problems // Uspechi Physicheskich Nauk. - 1989. - Vol. 159. - No. 1. - P. 155-180. (in Russian)

13. Dubovik A.S., Apenko M.I., Durejko G.V. Applied optics. - M.: Nedra, 1982. -528 p. (in Russian)

14. Report of the Physico-Technical Institute of the Ukrainian Academy of Sciences USSR No. 1021, 1955. The idea of multiple reflection // Journal of Technical Physics. - 1959. - Vol. 29. - P. 491. (in Russian)

15. Lima J.A.S., Sasse F.D. Can Lorentz transformations be determined by the null Michelson-Morley result? (2017) Arxiv.org/abs/1709.06864

16. David B. Parke. How to explain the Michelson-Morley experiment in ordinary 3-dimensional space (2010) $\underline{\text { ArXiv:1006.4596 }}$ [physics.gen-ph]

17. Masanori Sato. Single photon Michelson-Morley experiment via de Broglie-Bohm picture: An interpretation based on the hypothesis of frame dragging (2008) ArXiv:0801.3138 [physics.gen-ph]

18. Cahill R.T. The Michelson and Morley 1887 Experiment and the Discovery of Absolute Motion (2005)_Arxiv.org/abs/physics/

19. Kupriaev N.V. Michelson-Morley experiment and classical mechanics. Reports of independent authors, ed. «DNA». - RussiaIsrael, 2005. - Iss. 1. 